\title{
Trace Elements Composition and Enzymes Activity of Soil Amended with Municipal Sewage Sludge at Three Locations in Kentucky
}

\author{
George Fouad Antonious*, Eric Todd Turley \\ Division of Environmental Studies, College of Agriculture, Communities, and the Environment, Kentucky State University, Frankfort, USA
}

Email address:

george.antonious@kysu.edu (G. F. Antonious)

${ }^{*}$ Corresponding author

To cite this article:

George Fouad Antonious, Eric Todd Turley. Trace Elements Composition and Enzymes Activity of Soil Amended with Municipal Sewage Sludge at Three Locations in Kentucky. International Journal of Applied Agricultural Sciences. Vol. 6, No. 5, 2020, pp. 89-95.

doi: 10.11648/j.ijaas.20200605.11

Received: April 13, 2020; Accepted: April 30, 2020; Published: September 23, 2020

\begin{abstract}
Biological monitoring is a sensitive indicator of soil ecological stress for early restoration. The addition of manure, such as sewage sludge (SS) to agricultural soil contributes to the enhancement of organic compounds. However, SS may contain toxic metals that potentially affect soil microbial growth and the enzymes they produce. Soil samples were collected from three agricultural locations in Kentucky (Adair, Meade, and Franklin Counties), from areas where municipal SS was applied as a soil amendment for commercial crop production. The objectives of this investigation were to: 1) assess the impact of mixing native agricultural soil with municipal SS on the activities of the three enzymes that hydrolyze urea (urease, urea amidohydrolase, EC 3.5.1.5), sucrose (invertase, $\beta$-D-fructofuranosidase), and p-nitrophenyl phosphate (acid and alkaline phosphatase) and 2) determine total microbial activity using the fluorescein diacetate reagent. The concentrations of $\mathrm{Cr}, \mathrm{Ni}, \mathrm{Cu}$, $\mathrm{Zn}, \mathrm{Pb}$, and $\mathrm{C}$ content in soil mixed with $\mathrm{SS}$ in Franklin location were greater compared to Adair and Meade locations. The elevated soil urease and invertase activities ( 47 and $89 \%$, respectively) as well as acid and alkaline phosphatase activities (23 and $26 \%$, respectively) in soil amended with SS provided evidence of increased soil microbial population and the enzymes they produce.
\end{abstract}

Keywords: Biosolids, Urease. Invertase, Phosphatase, Total Enzymes Activity, Soil Management Practice

\section{Introduction}

With increasing cost and shortage of inorganic nitrogen fertilizers, there is increased emphasis on use of municipal sewage sludge (SS) for land farming. SS refers to the residual, semi-solid material that is produced as a by-product during sewage treatment of industrial or municipal wastewater. SS is inexpensive, locally available in large amounts, source of organic matter, and its use in growing horticultural crops provides a partial solution to its disposal problem. SS, a byproduct of sewage treatment plants, is currently applied to some agricultural soils as an alternative to conventional inorganic fertilizers. Microorganisms in soil, play a significant role in keeping three main nutrients $(\mathrm{C}, \mathrm{N}$, and $\mathrm{P})$ through recycling from organic matter. Soil microorganisms (bacteria, fungi, protozoa, algae) excrete a variety of enzymes (ureases, invertases, dehydrogenases, cellulases, amylases, and phosphatase) that are primary means of degrading xenobiotics (manmade pollutants) in soil and water systems, mineralization of organic compounds, and release of nutrients for plant uptake. Soil enzymes are sensitive indicators to environmental stress caused by soil pollution [1]. Accordingly, soil enzymatic measurements could be explored as a biological index of soil fertility and microbiological processes.

In order to monitor crop response to soil organic matter after addition of SS, one approach is to monitor soil enzyme activities. Application of organic amendments to agricultural soils makes a good use of natural resources and reduces the need of synthetic inorganic fertilizers. Agriculture in the state of Kentucky is a major industry and many farmers are limited resource farmers (LRF). LRF are 
continually searching for alternatives to synthetic fertilizers to alleviate the production costs associated with the increasing costs of fertilizers and the problems of soil deterioration and erosion associated with intensive farming systems. As more communities produce SS compost, there is increased interest in its application to agricultural crops including high value horticultural crops. The positive aspects of using SS compost may outweigh its negative aspects (such as presence of trace-elements) due to its ability to increase soil organic matter content [2] and crop yield [3, 4]. Despite their relatively low amounts, soil microorganisms play a significant role in keeping the main nutrients (carbon, nitrogen, and phosphorus) in soil. Urease (urea amidohydrolase, EC 3.5.1.5) is the enzyme that catalyzes the hydrolysis of urea to $\mathrm{CO}_{2}$ and $\mathrm{NH}_{4}^{+}$ions (Figure 1A) by acting on $\mathrm{C}-\mathrm{N}$ non-peptide bonds in linear amides. It is an important enzyme in soil that mediates the conversion of organic nitrogen to inorganic nitrogen by hydrolysis of urea to ammonia. Invertase ( $\beta$-Dfructofuranosidase) is ubiquitous enzyme that catalyzes the hydrolysis of sucrose to glucose and fructose (Figure 1B). The activities of urease and invertase are important in soil for releasing simple carbon and nitrogen sources for plant growth and multiplication of soil microorganisms. Phosphatases, a group of enzymes that catalyze the hydrolysis of esters and anhydrides of phosphoric acid $\left(\mathrm{H}_{3} \mathrm{PO}_{4}\right)$, catalyze the hydrolysis of organic phosphate esters to orthophosphate (Figure 1C), and thus constitutes an important link between biologically unavailable and bioavailable phosphorus pools in the soil. Phosphatases are ubiquitous in soil and are produced by microorganisms in response to low levels of inorganic phosphates. Accordingly, the study of soil enzymes activities is important since they reveal the potential of a soil to carry out specific biochemical reactions for maintaining soil quality and fertility.

Recycling wastes would reduce dependence on synthetic fertilizers and provides amendments useful for improving soil structure and nutrient status [5]. The benefits of organic amendments to growth and yield of vegetables have been clearly demonstrated [6, 7]. The U.S. Environmental Protection Agency (USEPA) promotes the safe use of municipal solids for land farming because it decreases dependence on synthetic fertilizers and provides significant economic advantages, such as reducing the needs for waste disposal sites. SS contains organic matter, and macro- and micro-nutrients important for plant growth. In addition, the simultaneous use of soil conditioners, such as SS, to enhance soil physical, chemical, and microbial conditions could also enhance soil bioremediation [8,9]. Agricultural uses of SS have shown promise for a variety of field crops and production of vegetables [3, 4]. Most agricultural benefits of SS application to soil are derived from improved physical properties related to the increased organic matter content, nutrient and water holding capacity, total pore space, aggregate stability, erosion resistance, temperature insulation, and decreasing apparent soil density [10]. In addition, the addition of organic waste to soil contributes to enhancement of active humified components, such as humic acid (HA) and fulvic acid (FA) [11], which exert an important role in geochemical processes as source of nutrients for plants and microorganisms, in acid-base buffering capacity of soils, and in promoting a good soil structure, thereby improving aeration and moisture retention $[12,13]$.

Accordingly, in agronomic aspects, addition of organic waste enhances soil biological activity and fertility and provide nutrients and diverse groups of microorganisms, such as bacteria, fungi, and actinomycetes [14-18] that mineralize complex forms soil nutrients.

The objectives of this investigation were to: 1) assess the impact of mixing native agricultural soil with municipal SS at three locations in Kentucky (Adair, Meade, and Franklin Counties) on the activities of the three soil enzymes that hydrolyze urea (urease), sucrose (invertase), p-nitrophenyl phosphate (acid and alkaline phosphatase) and 2) determine total soil enzymes activity using the fluorescein diacetate reagent.

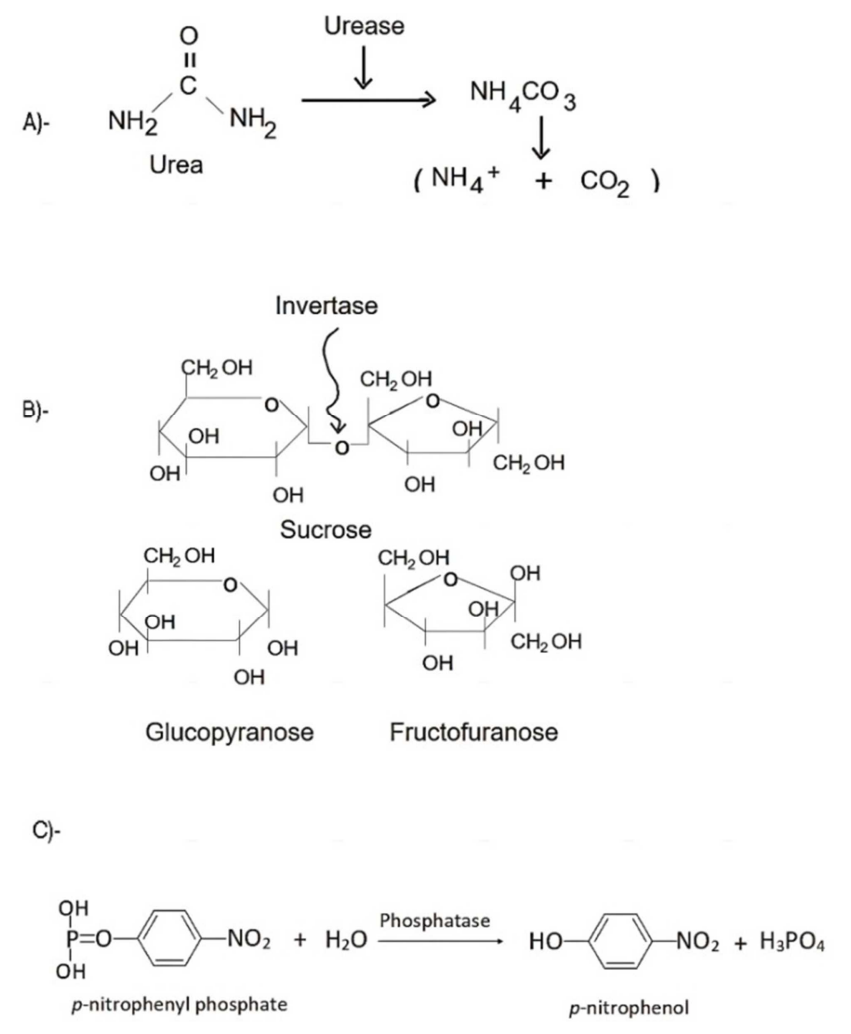

Figure 1. Diagram of soil enzymatic reactions with their substrates and hydrolysis products of urease (A), invertase (B), and phosphatase (C).

\section{Methods}

Three field experiments were conducted at three locations in Kentucky (Adair, Meade, and Franklin Counties). In each location, plots $(n=15)$ of $2 \times 10 \mathrm{~m}$ each were separated using grass strips. The soil in five plots was mixed with municipal SS trade market as "Louisville Green" obtained from Metropolitan Sewer District, Louisville, KY and applied at 
$15 \mathrm{tacre}^{-1}$ on dry weight basis. Pure SS in five plots was used alone as a top soil at $15 \mathrm{t} \mathrm{acre}^{-1}$ on dry weight basis, and native soil in five plots was used as a no-mulch (NM) control treatment (roto-tilled bare soil) for comparison purposes. SS mixed with native soil was incorporated into the top soil with a plowing depth of $15 \mathrm{~cm}$. Potatoes (Ipomoea batatus cv. Kennebec) plants were grown from tuber cuttings and planted according to Kentucky growers' guidelines [19]. Thirty-cm of extra space was allowed between planting rows, and the plants were watered, irrigated, and weeded as needed, but no mineral fertilizer was applied during the growing season.

Soil samples $(n=3)$ were collected from the rhizosphere (a zone of increased microbial and enzyme activity where soil and root make contact) of growing potato plants to a depth of $15 \mathrm{~cm}$ using a core sampler equipped with a plastic linear tubes tube (Clements Associates, Newton, IA) of 2.5 $\mathrm{cm}$ i. d. for maintenance of sample integrity. Soil samples were air-dried, passed through a $2 \mathrm{~mm}$ sieve, and kept in plastic bags at $4^{\circ} \mathrm{C}$ up to $24 \mathrm{~h}$ before use. Soil $\mathrm{pH}$ was determined using a glass electrode in a soil: distilled water slurry $(1: 5, \mathrm{w} / \mathrm{v})$. Soil organic matter was calculated as dry weight minus ash content [20]. Nitrogen (N) was determined by the Kjeldahl method [21]. Cr, Ni, $\mathrm{Cu}, \mathrm{Zn}$, $\mathrm{Mo}, \mathrm{Cd}, \mathrm{Pb}$, and $\mathrm{C}$ were determined using an Inductively Coupled Plasma Spectrometer after digestion and extraction with $\mathrm{HNO}_{3}$ [22].

For determination of urease activity, five $\mathrm{g}$ of soil were placed in $50 \mathrm{~mL}$ volumetric flasks and $10 \mathrm{~mL}$ of $0.1 \mathrm{M}$ phosphate buffer ( $\mathrm{pH}$ 6.7) was added to each flask. The flasks were incubated for 24 hours at $37^{\circ} \mathrm{C}$ and the procedure was completed as described by Tabatabi and Bremner [23]. Concentrations of $\mathrm{NH}_{4}^{+}$ions were determined by the selective electrode method [21]. A series of standard solutions of $\mathrm{NH}_{4} \mathrm{Cl}$ covering the concentrations of $0.1-100 \mu \mathrm{g}$ $\mathrm{NH}_{4}-\mathrm{N} \mathrm{mL} \mathrm{m}^{-1}$ of water was used for calibration. Urease activity was expressed as $\mu \mathrm{g} \mathrm{NH}_{4}-\mathrm{N}$ released per $\mathrm{g}$ dried soil [5]. Invertase activity in soil was estimated by the method described by Balasubramanian et al. [24]. A standard calibration curve was obtained with each group of samples using analytical grade glucose in the range of $10-50 \mu \mathrm{g} \mathrm{mL}^{-1}$ glucose standards (Sigma Chemical Company, St. Louis, MO, USA). Acid and alkaline phosphatase activities in soil were determined by the method developed by Tabatabai and Bremner [25] which determines p-nitrophenol released when soil is incubated with buffered sodium p-nitrophenol phosphate solution ( $\mathrm{pH} 6.7$ for acid phosphatase assay and $\mathrm{pH} 11$ for alkaline phosphatase assay). A standard curve containing $0-50 \mu \mathrm{g} \mathrm{mL}^{-1}$ of p-nitrophenol was used for calibration.

Spectrophotometric determination of the hydrolysis of fluorescein diacetate [3, 6-diacetylfluorescein (FDA)] was used for measuring total soil enzyme activities. The activity of total soil enzyme classes including urease, invertase, phosphastases, lipases, esterases, and proteases results in the hydrolytic cleavage of FDA (colorless) into fluorescein (fluorescent yellow-green color). In this assay, $2 \mathrm{~g}$ soil sample were mixed with $0.2 \mathrm{~mL}$ of FDA in $15 \mathrm{~mL}$ of potassium phosphate buffer $(\mathrm{pH}$ 7.6) and incubated for 30 min at $30^{\circ} \mathrm{C}$. The intensity of the resulting yellow-green color at $490 \mathrm{~nm}$ wavelength is indicative of the amount of enzymatic cleavage of the FDA molecule and the overall enzymatic activity in soil samples. Quantification of total soil enzyme activity was performed by measuring the intensity of color formation using a spectrophotometer [26, 27]. Total soil enzymes activities were expressed as FDA concentration in $\mu \mathrm{g} \mathrm{g}^{-1}$ dry soil. The activities of urease, invertase, acid and alkaline phosphatases, and total soil enzymes activity were compared using analysis of variance [28] and Duncan's multiple range test for mean comparisons.

\section{Results and Discussion}

Regardless of soil location, results indicated that the activity of native soil invertase and urease were significantly $(P<0.05)$ enhanced due to addition of SS (Figure 2A). Invertase and urease activities were increased by 89 and $47 \%$, respectively in soil mixed with SS compared to native soil. Similarly, acid and alkaline phosphatase activities increased by 23 and $26 \%$, respectively (Figure 2B) after soil incorporation with SS. In addition, regardless of soil treatments, urease activity was greater in soil samples collected from Meade location compared to Adair and Franklin locations. Whereas, invertase activity was significantly greater in both Franklin and Meade locations compared to Adair location (Figure 3A). Acid and alkaline phosphatase activities in Adair and Meade were greater than Franklin location (Figure 3B). The increase in urease activity associated with SS addition may be explained by the presence of urea, the substrate of the enzyme in SS compost. According to Garcia et al. [29], SS contains high amounts of enzymatic substrates. These easily available substrates stimulate microbial growth and enzymes secretion. Low enzymatic activity in native soil could be due to low concentrations of substrate (urea), decreased enzyme synthesis associated with inhibited microbial growth, or trace-metal inhibition of the enzyme by masking the active groups, by protein denaturation, or by effects on enzyme configuration. Accordingly, the discrepancies found among three locations in Kentucky (Figure 3) are partly due to the fact that soils collected in this study have different trace metals composition (Table 1), which impact enzyme activities. The concentrations of $\mathrm{Cr}$, $\mathrm{Ni}, \mathrm{Cu}, \mathrm{Zn}, \mathrm{Pb}$, and $\mathrm{C}$ content in soil mixed with $\mathrm{SS}$ in Franklin location were significantly higher compared to Adair and Meade locations (Table 1), $\mathrm{Zn}$ for example inhibits urease activity [30] and this could be the reason of the lower urease activity in Franklin soil amended with SS (Figure 3A). 

Amended with Municipal Sewage Sludge at Three Locations in Kentucky

Table 1. Trace metals in municipal sewage sludge (SS) amended with native soil at three agricultural locations in Kentucky (Adair, Meade, and Franklin).

\begin{tabular}{|c|c|c|c|}
\hline \multirow{2}{*}{ Soil Content } & Adair SS mixed with Native Soil & Meade SS mixed with Native Soil & Franklin SS mixed with Native Soil \\
\hline & \multicolumn{3}{|l|}{$\mu \mathrm{g} \mathrm{g}^{-1}$ dry weight } \\
\hline $\mathrm{Cr}$ & $0.05 \mathrm{~b}$ & $0.09 \mathrm{~b}$ & $16.58 \mathrm{a}$ \\
\hline $\mathrm{Ni}$ & $1.05 \mathrm{~b}$ & $0.88 \mathrm{~b}$ & $17.30 \mathrm{a}$ \\
\hline $\mathrm{Cu}$ & $1.08 \mathrm{c}$ & $3.65 \mathrm{~b}$ & $13.87 \mathrm{a}$ \\
\hline $\mathrm{Zn}$ & $0.63 \mathrm{c}$ & $11.02 \mathrm{~b}$ & $66.17 \mathrm{a}$ \\
\hline Mo & $0.87 \mathrm{a}$ & $0.11 \mathrm{~b}$ & $0.00 \mathrm{~b}$ \\
\hline $\mathrm{Cd}$ & $0.87 \mathrm{a}$ & $0.23 \mathrm{~b}$ & $0.17 \mathrm{~b}$ \\
\hline $\mathrm{Pb}$ & $4.87 \mathrm{c}$ & $8.05 \mathrm{~b}$ & $29.30 \mathrm{a}$ \\
\hline$\% \mathrm{C}$ & $1.89 \mathrm{~b}$ & $2.52 \mathrm{~b}$ & $3.70 \mathrm{a}$ \\
\hline$\% \mathrm{~N}$ & $0.18 \mathrm{a}$ & $0.31 \mathrm{a}$ & $0.39 \mathrm{a}$ \\
\hline$\%$ Organic Matter & $3.1 \mathrm{~b}$ & $4.3 \mathrm{a}$ & $4.3 \mathrm{a}$ \\
\hline $\mathrm{pH}$ & $5.5 \mathrm{~b}$ & $7.3 \mathrm{a}$ & $7.6 \mathrm{a}$ \\
\hline
\end{tabular}

Each value is an average of analysis of three replicate samples.

$\%$ Organic matter was calculated as dry weight minus ash content.

$\mathrm{pH}$ was determined using a glass electrode in a soil: distilled water slurry $(1: 5 \mathrm{~W} / \mathrm{V})$. Values accompanied by the same letter in each row are not significantly different $(P>0.05)$. Statistical comparisons were carried out among amended soils at three locations using Duncan's multiple range test.
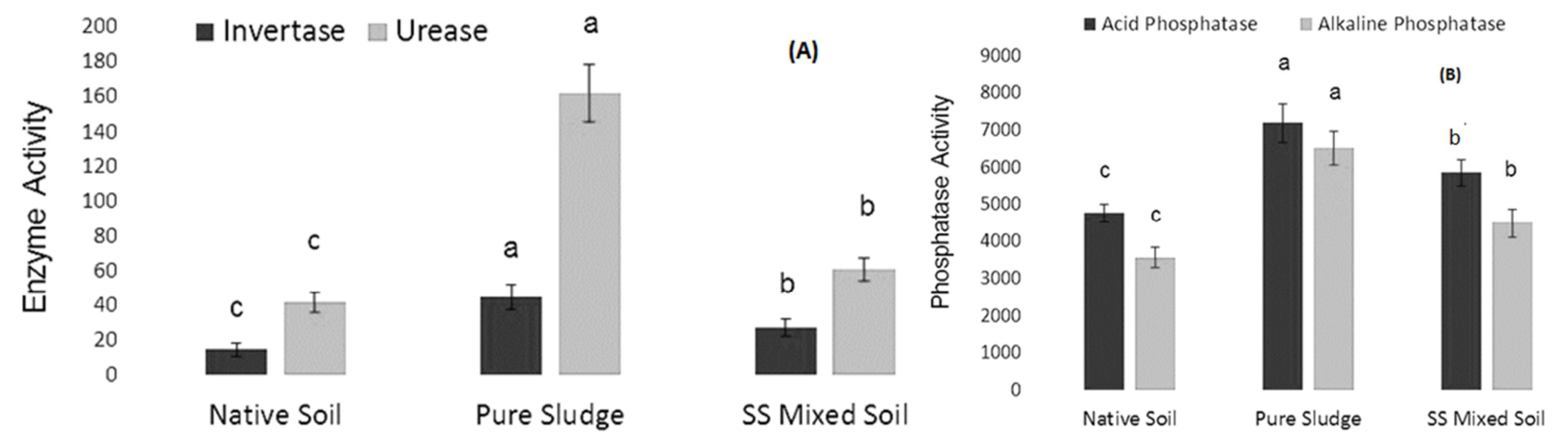

Figure 2. Invertase activity expressed as $\mu \mathrm{g}$ glucose released $\mathrm{g}^{-1}$ dry soil, urease activity expressed as $\mu \mathrm{g} \mathrm{NH}_{4}-\mathrm{N}$ released $g^{-1}$ dry soil hr $r^{-1}$ (A) and acid, and alkaline phosphatase activity expressed as $\mu \mathrm{g}$ para-nitrophenol released $g^{-1}$ dry soil $h^{-1}$ (B). Statistical comparisons were carried out among three soil management practices. Bars accompanied by the same letter are not significantly different $(P>0.05)$ using Duncan's multiple range test.

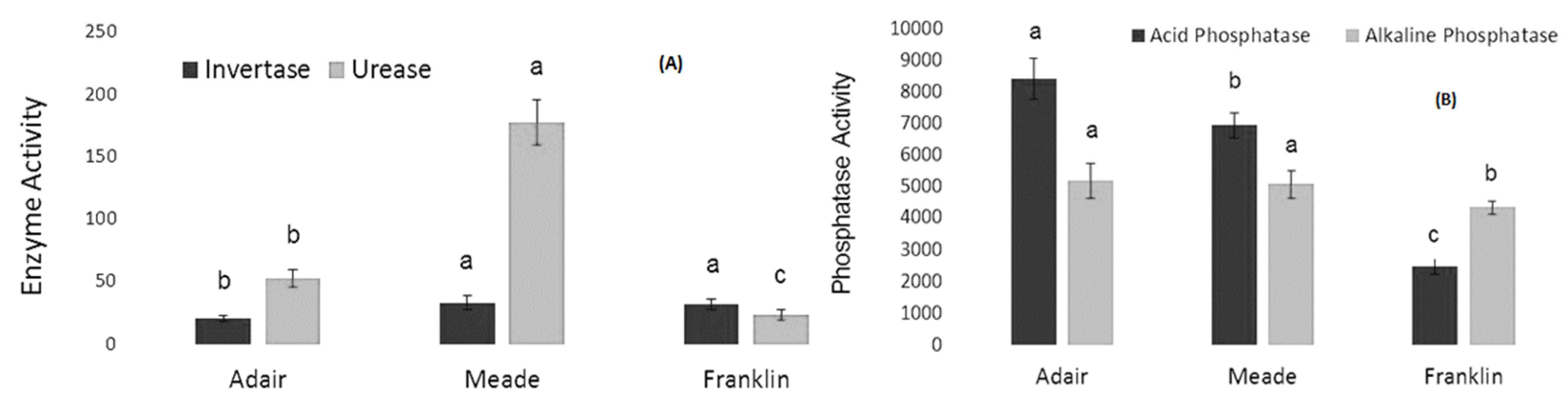

Figure 3. Invertase activity expressed as $\mu \mathrm{g}$ glucose released $g^{-1}$ dry soil, urease activity expressed as $\mu g \mathrm{NH}_{4}-\mathrm{N}$ released $g^{-1}$ dry soil hr $r^{-1}$ (A), and acid and alkaline phosphatase activity expressed as $\mu \mathrm{g}$ para-nitrophenol released $\mathrm{g}^{-1}$ dry soil $\mathrm{hr}^{-1}(B)$. Statistical comparisons were carried out among soil samples collected from three Kentucky counties. Bars accompanied by the same letter are not significantly different (P>0.05) using Duncan's multiple range test.

Overall enzyme activities determined using the FDA reagent, revealed that total soil enzyme activities were significantly $(P<0.05)$ greater in SS amended soil compared to no-mulch native soil. This could be explained by the increase in soil fertility, microbial population, and the hydrolysis of FDA reagent by the enzymes secreted in the soil by microorganisms after the addition of SS (Figure 4). Microbial activity and soil fertility are closely related.

Total enzyme activity increased from 9.7, 6.9, and 9.3 in native soils from Meade, Adair, and Franklin locations to 21, 17, and $22 \mu \mathrm{g} \mathrm{FDA} \mathrm{g}^{-1}$ dry soil, respectively (Figure 4) after addition of SS to native soil. This increase has provided evidence of increased soil microbial activities and the enzymes produced. The literature review revealed that the addition of organic amendments such as yard waste compost [5] straw [31] manure [32] tree leaf mulch [33] wood products [34] and chipped wood from twigs [35] have been found to reduce the negative effects of xenobiotics (manmade pollutants) on soil microbial populations and their enzyme secretions due to the increased content of organic matter and its role in sorption processes of organic pollutants [36-38]. This is due to the increase in humic substances containing carbonyl, carboxyl, phenolic, and alcohol functional groups [39]. Binding of organic pollutants to humic substances in 
recycled wastes such as SS protects microorganisms from the toxic effects of xenobiotics such as trace metals in SS.

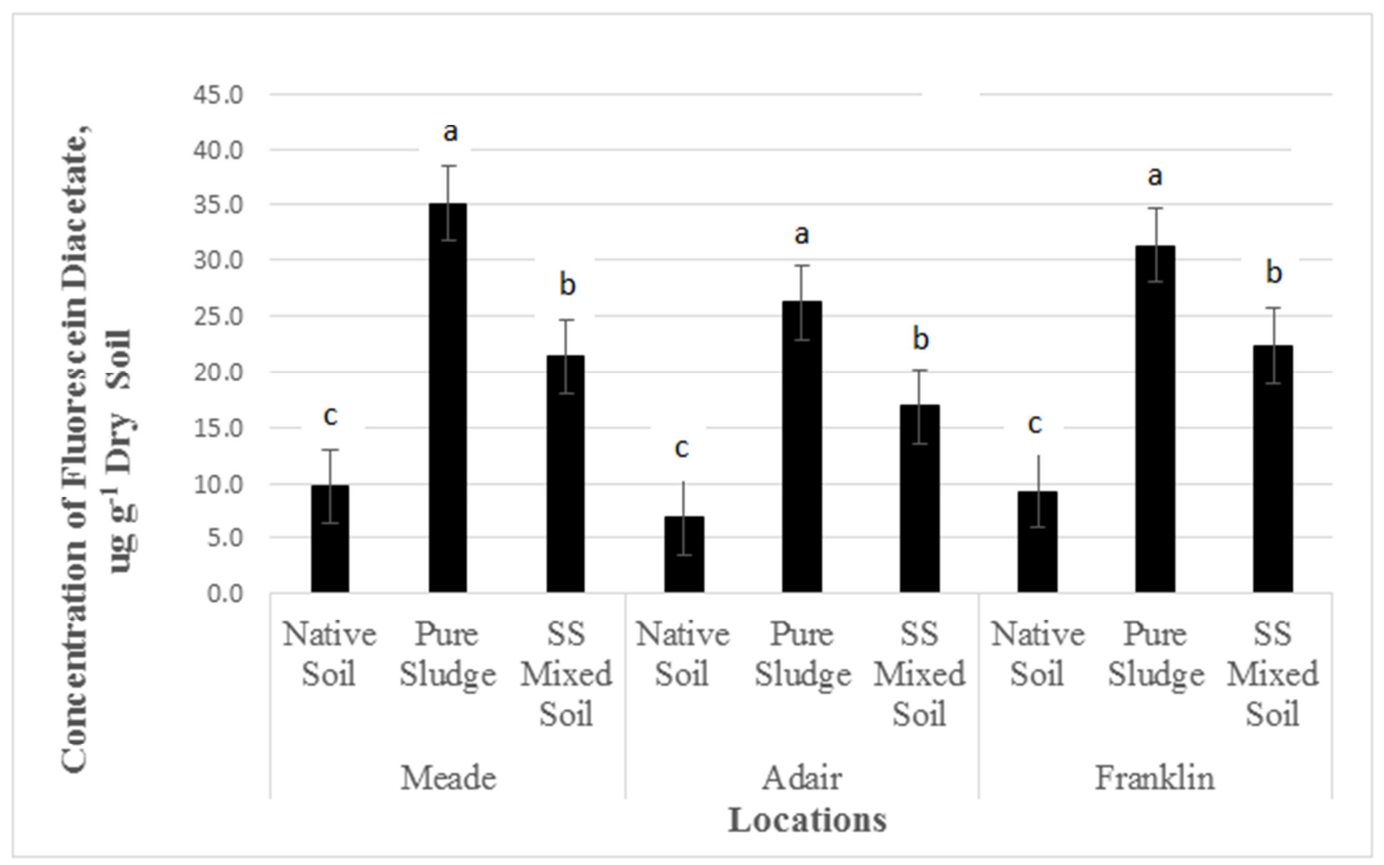

Figure 4. Concentrations \pm std. error of total soil enzymes activity expressed as $\mu g g^{-1}$ fluorescein diacetate released $g^{-1}$ dry soil $h r^{-1}$ at three locations in Kentucky. Statistical comparisons were carried out among soil samples collected from three location. Bars accompanied by the same letter are not significantly different $(P>0.05)$ using Duncan's multiple range test.

This increase of organic matter in soil after addition of SS has a great impact on the biological and biochemical properties of soil [40]. However, some organic wastes are associated with inorganic and organic toxic compounds (trace-metals and pesticide residues) that when incorporated into soil, constitute a pollution problem - by affecting soil microorganisms and the enzymes they produce and consequently lessen the growing plants. Accordingly, soil enzymes could be tracked as indicators of soil quality following the addition of soil amendments to monitor the presence and activities of soil microorganisms prior to implanting animal manure or throughout the growing season. Different species of bacteria, viruses and parasites are found in animal manure, which are mainly derived from the digestive tract of the animal. The most numerous group in manure is bacteria, with typical numbers at about 1010 bacteria $\mathrm{g}^{-1}$ dry manure, dominated by faecal coliforms and streptococci [41]. Soil incorporation of SS compost increased urease and invertase activities in soil, indicating their stimulation and enzymes production by microflora. In addition, it has become common practice to add organic matter such as SS to contaminated soils for bioremediation $[42,43]$.

The immobilization of pollutants in agricultural soil has been recognized as a promising technique for removing trace metals from soil mixed with animal manures, preventing their accumulation in edible plants, and protecting soil biota. Immobilization of hazardous trace metals through binding to soil amendments reduces hazardous compounds from leaching through the soil column and prevents groundwater contamination. Organic matter in soil amendments provides a partial solution to environmental contamination. Investigators reported that SS added to agricultural soil increased the organic matter content from 1.4 to $4.8 \%$ when applied at $20 \mathrm{~g}$ $\mathrm{kg}-1$ while, the estimated trace metals in soils were either below $\mathrm{Cu}, \mathrm{Fe}, \mathrm{Mn}, \mathrm{Mo}, \mathrm{Zn}$, and $\mathrm{Pb}$ or within $\mathrm{Co}, \mathrm{Ni}, \mathrm{Cd}$, and $\mathrm{Cr}$ maximum permissible levels [44]. In addition, MierzwaHersztek et al. [45] reported a positive correlation between microbial population and soil $\mathrm{pH}$. Mixing SS amended soil with lime (calcium carbonate) or biochar (a carbon-rich product obtained when biomass, such as wood, manure, or leaves, is heated in a closed container) has been proposed to reduce soil contamination by trace metals due to their impact soil $\mathrm{pH}[46,47]$. In addition, biochar is effective at retaining water- soluble nutrients required for many beneficial soil microorganisms [48].

Crop producers looking for cost-effective sources of $\mathrm{N}, \mathrm{P}$, and $\mathrm{K}$ nutrients have found that the use of animal manure is a cost-effective way to meet their requirements [48]. Organic farming requires organic fertilizers. There is a growing scientific evidence about the positive quality aspects of organically produced food like higher dry matter, vitamin content, and improved storage quality. Unlike conventional agriculture, organic farming has not been blessed with extensive research and development [46].

\section{Conclusion}

Increasing costs of commercial fertilizers and release of large amounts of municipal sewage sludge (SS) worldwide have made cropland application of this waste an attractive disposal option. This investigation has focused on one type of 
municipal SS. Accordingly, these results cannot be generalized to different sources of sludge. Soil incorporation of SS compost used in this investigation increased urease, invertase, and phosphatase activities in soil, indicating their stimulation and production by microflora. In recent years, it has become common practice to add organic matter to contaminated soils for their bioremediation [42, 43]. Studies have highlighted the role of organic matter in the sorption processes of organic pollutants, probably due to the presence of humic substances containing several major functional groups, such as carboxyl, phenolic, alcohol, and carbonyl that form stable combinations of organic pollutants with organic matter lowering the impact of toxic compounds on soil microorganisms that secretes hydrolyzing enzymes.

\section{Acknowledgements}

We thank Kentucky limited-resource farmers (Mr. Norman Watts, Mr. Larry Sims, and Mr. Harvel Escue) who provided their agricultural fields for conducting this investigation. This investigation was supported by a grant from the United States Department of Agriculture, National Institute of Food and Agriculture (USDA/NIFA) to Kentucky State University under agreement No. KYX-1018-65P Accession 1017900.

\section{References}

[1] Angelovicova L, M Lodenius, E Tulisalo, D Fazekasova. Effect of heavy metals on soil enzyme activity at different field conditions. In Middle Spis mining area (Slovakia). Bull Environ Contam Toxicol 2014, 93: 670-675.

[2] Hargreaves JC, MS Adl, PR Warman. A review of the use of composted municipal solid waste in agriculture. Agr. Ecosyst. Environ. 2008, 123: 1-14.

[3] Antonious, GF. Impact of soil management practices on yield, fruit quality, and antioxidant contents of pepper at four stages of fruit development. J. Environmental Sci. Health, 2014, Part B49: 769-774.

[4] Antonious GF, ET Turley, RR Hill, JC Snyder. Effect of municipal refuse and chicken manure applications on kale and collard green yields and quality, Fruit and Vegetable Research Report, December 30, 2013, PR-673, pages 37-39, University of Kentucky, College of Agriculture, Food and Environment, Lexington, KY 40546.

[5] Antonious G. F. (2003). Impact of soil management and two botanical insecticides on urease and invertase activity. J. Environ. Sci. Health 38: 479-488.

[6] Ozores-Hampton M, R Peach. Biosolids in vegetable production systems. Hort. Technology 2002, 12 (3), 336340.

[7] Antonious GF. Enzyme activities and heavy metals concentration in soil amended with sewage sludge. J. Environ. Science \& Health, Part-A Toxic/Hazardous Substances \& Environmental Engineering, 2009, A44, Issue No. 10, p 10191024.
[8] Terry RE. Use of soil conditioners to enhance and speed bioremediation of contaminated soils. In: Handbook of Soil Conditioners. Wallace, A., Terry, R. E., Eds., Marcel Dekker Inc., New York, 1998, 551-751.

[9] Antonious GF, JC Snyder. Accumulation of heavy metals in plants and potential phytoremediation of lead by potato, Solanum tuberosum L. J. Environ. Sci. Health 2007, A42, 811-816.

[10] Shiralipour A, DB McConnell, WH Smith. Physical and chemical properties of soils as affected by municipal solid waste compost application. Biomass and Bioenergy 1992, 3, 261-266.

[11] Plaza C, A Polo, G Brunetti, J Garcia-Gil, V D’Orazio. Soil fulvic acid properties as a means to assess the use of pig amendment, Soil Till. Res. 2003, 74: 179-190.

[12] Graber E., I Dror, F Bercovich, M Rosner. Enhanced transport of pesticides in a field trial with treated sewage sludge, Chemosphere 2001, 44: 805-811.

[13] Marschner P, E Kandeler, B Marschner. Structure and function of the soil microbial community in a long-term fertilizer experiment, Soil Biol. Biochem. 2003, 35: 453-461.

[14] Namkoong W, E Hwang, J Park, J Choi. J. Bioremediation of diesel contaminated soil with composting, Environ. Pollut. 2002, 119: 23-31.

[15] Zagal E, N Rodr'iguez, I Vidal, L Quezada. Actividad microbiana en un suelo de origen volc'anico bajo distinto manejo agron'omico, Agri. T'ec. 2002, 62: 297-309.

[16] Dungan, R., A Ibekwe, S Yates. Effects of propargyl bromide and 1.3-dichloropropene on microbial communities in an organycally amended soil, FEMS Microbiol. Ecol. 2003, 43: $75-87$.

[17] B"ohme, L., U Langer, F B"ohme. Microbial biomass, enzyme activities and microbial community structure in two European long-term field experiments, Agric. Ecosyst. Environ. 2005, 109: $141-152$.

[18] Wanner, U., F F"uhr, P Burauel. Influence of the amendment of corn straw on the degradation behaviour of the fungicide dithianon in soil, Environ. Pollution 2005, 133: 63-70.

[19] Saha SK, E Pfeufer, R Bessin, S Wright, J Strang. Vegetable Production Guide for Commercial Growers, Cooperative Extension Service Bulletin ID-36, University of Kentucky, College of Agriculture, 2016, Lexington, KY, ID-36.

[20] McLaren AD, AH Pukite, I Barshad. Isolation of humus with enzymatic activity from soil. Soil Sci. 1975, 119: 178-180.

[21] American Public Health Association (APHA). Standard methods for the determination of water and wastewater, 19th ed. 1995.

[22] EPA. Method 6020a: Inductively coupled plasma -mass spectrometry. USEPA: Washington, DC, 1998.

[23] Tabatabi MA, JM Bremner. Assay of urease activity in soils. Soil Biol. Biochem. 1972, 4: 479-487.

[24] Balasubramanian, D, DJ Bagyaraj, G Rangaswami. Studies on the influence of foliar application of chemicals on the microflora and certain enzyme activities in the rhizosphere of Eleusine coracana Gaertn. Plant Soil 1970, 32: 198-206. 
[25] Tabatabai MA, JM Bremner. Use of p-nitrophenol phosphate for assay of soil phosphatase activity. Soil Biol. Biochem. 1969, 1: 301-307.

[26] Chakrabarti K, P Bhattacharya, A Chakraborty. Effects of metal-contaminated organic wastes on microbial biomass and activities: A review. In: Heavy Metal Contamination of Soil, Ahmed I., Hayat S, and Pichtel J. (eds), Scince Publishers, Inc., Plymouth, UK, 2005, p 195-204.

[27] Antonious GF. Enzymatic activity and half-lives of capsaicin, dihydrocapsaicin, and pentadecanoic acid methyl ester in soil sprayed with hot pepper extract. J. Environmental Science and Health, 2013. Part-B, 48: 836-843.

[28] SAS Institute Inc. SAS/STAT Guide, Version 6.4 SAS Inc., Campus Drive, Cary, NC 27513; 2016.

[29] Garcia C, T Hernandez, C Costa, B Ceccanti, G Masciandaro, C Ciardi. A study of biochemical parameters of composted and fresh municipal wastes. Bioresource Technology 1993, 44: $17-23$

[30] Yang, Z., Liu, S., Zheng, D., Feng, S. (2006). Effects of cadmium, zinc and lead on soil enzyme activities. J. Environmental Sciences 18, 6, 1135-1141.

[31] Kucharski J, E Jastrzebska, J Wyszkowska, A Hlasko. Effect of pollution with diesel oil and leaded petrol on enzymatic activity of the soil. Zesz. Probl. Postpep. Nauk Rol. 2000, 472: 457-464.

[32] Moore PA, TC Daniel, JT Gilmour, BR Shreve, DR Edwards, BH Wood. Decreasing metal runoff from poultry litter with aluminum sulfate. J Environ Quality 1998, 27: 92-99.

[33] Acosta-Martinez V, Z Reicher, M Bischoff, RF Turco. The role of tree leaf mulch and nitrogen fertilizer on turfgrass soil quality. Biol. Fertil. Soils 1999, 29: 55-61.

[34] Straton ML, JE Rechcigl. Organic mulches, wood products, and compost as soil amendments and conditioners. In: Handbook of soil conditioners. Wallace A, Terry R (eds), Marcel Dekker, Inc., 1998, New York, pp. 43-95.

[35] Lalande R, V Furlan, DA Angers, G Lemieux G. Soil improvement following addition of chipped wood from twigs. Amer. J. Altern. Agric. 1998, 13: 132-137.

[36] Gunasekara AS, B Xing. Sorption and desorption of naphthalate by soil organic matter. J. Environ. Qual. 2003, 32: 240-246.

[37] Antonious GF, GA Patel, JC Snyder, MS Coyne. Pyrethrins and piperonyl butoxide adsorption to soil organic matter. J. Environ. Sci. Health 2004, B39: 19-32.

[38] Antonious GF, JC Snyder. Impact of soil incorporated sewage sludge on herbicide and trace metal mobility in the environment, In: Environmental Engineering \& Economics, published 2006 by Dr. Michael Theophanides, Institute for Education \& Research, Athens, Greece, Chapter 12, pages 149-164.

[39] Datta A, SK Sanyal, S Saha. A study on natural and synthetic humic acids and their complexing ability towards cadmium. Plant Soil 2001, 235: 115-125.

[40] Tejada M, MT Hernandez, C Garcia. Application of two organic wastes in a soil polluted by lead: Effects on the soil enzymatic activities. J. Environ. Qual. 2007, 36: 216225 .

[41] Jensen, LS and Sommer, SG (2013). Manure Organic MatterCharacteristics and Microbial Transformations. Chapter 5, pages 67-87. In: Animal Manure Recycling Treatment and Management Edited by Sommer, SG.; Christensen, ML; Schmidt, T; and Jensen, LS. John Wiley \& Sons Ltd, The Atrium, Southern Gate, Chichester, West Sussex, PO19 8SQ, United Kingdom.

[42] Antonious GF, Z Ray, L Rivers. Sewage sludge reduced dimethoate residues in runoff water. UK Agricultural Experimental Station, Fruit \& Vegetable Crops Research Report 2007, \# PR-555, pp. 85-87, University of Kentucky, Lexington, KY 40546.

[43] Antonious GF Mobility and half-life of bensulide in agricultural soil. J. Environ. Science Health, Part-B Pesticides, Food Contaminants \& Agricultural Wastes, 2010, B45: 1-10.

[44] Eid, E. M., Hussain, A. A. Taher, M. A., Galal, T. M., Shaltout, K. H., Sewelam, N. (2020). Sewage sludge application enhances the growth of Corchorus olitorius plants and provides a sustainable practice for nutrient recirculation in agricultural soils. J. Soil Sci. Plant Nutrition 20, 149-159.

[45] Mierzwa-Hersztek, M., Gondek, K., Klimkowicz-Pawlas, A., Chmiel, M. J., Dziedzic, F., Taras, H. (2019). Assessment of soil quality after biochar application based on enzymatic activity and microbial composition. Int. Agrophys., 33, 331336.

[46] Antonious, GF (2016). Soil amendments for agricultural production. Chapter 7 In: Organic Fertilizers: From Basic Concepts to Applied Outcomes, Book chapter, pages 157-187. Edited by Larramendy ML \& Soloneski S, Published by Intech, Janeza Trdine 9, 51000 Rijeka, Croatia.

[47] Antonious, GF (2018). Biochar and animal manure impact on soil, crop yield and quality. Book Chapter In: Agricultural Waste. Edited by Prof. Anna Aladjadjiyan, National Biomass Association, Bulgaria \& Published by Intech- Open Science Books, Janeza Trdine 9, 51000 Rijeka, Croatia.

[48] Hein, T. (2016). Note your grandpa's poultry litter stockpile. Manure Manager, December issue, 10-12. 